\title{
Pembuatan File Input berbasis Chat untuk Screen-Smart Device Interaction (SSI)
}

\author{
Moh. Hasbi Assidiqi \\ Departemen Teknologi Multimedia \\ Kreatif \\ Politeknik Elektronika Negeri Surabaya \\ Surabaya, Indonesia \\ hasbi@pens.ac.id
}

\author{
Fani Isbat Fudhola \\ Departemen Teknologi Multimedia \\ Kreatif \\ Politeknik Elektronika Negeri Surabaya \\ Surabaya, Indonesia \\ fudholamu@gmail.com \\ Rosiyah Faradisa \\ Departemen Teknologi Multimedia \\ Kreatif \\ Politeknik Elektronika Negeri Surabaya \\ Surabaya, Indonesia \\ faradisa@pens.ac.id
}

\author{
Aliv Faizal Muhammad \\ Departemen Teknologi Multimedia \\ Kreatif \\ Politeknik Elektronika Negeri Surabaya \\ Surabaya, Indonesia \\ aliv@pens.ac.id
}

\begin{abstract}
Public displays have the potential to be a medium for disseminating information to the public. Unfortunately, the majority of public displays have a tendency to be ignored by the passersby. Some research shows that users will see a public display if they can interact with it. One approach is ScreenSmart Device Interaction (SSI). In this study, an interaction was developed to display a file from a smart device to a display using a Chat-based interface. Tests were carried out with the SUS and UEQ-S measuring instruments. From the test, it was concluded that the results developed were acceptable with a SUS score of 72.8. However, the UEQ-S obtained a lower hedonic score than pragmatic, which means that further development is needed regarding the appearance of the prototype being tested.
\end{abstract}

Keywords—public display, information medium, interaction design, chatbot, usability, disaster awareness

Abstrak- Public display memiliki potensi untuk menjadi media diseminasi informasi kepada publik. Sayangnya, mayoritas public display memiliki kecenderungan untuk diabaikan oleh orang-orang yang melewatinya. Beberapa riset menunjukkan bahwa pengguna akan melihat sebuah public display jika dapat berinteraksi dengan display tersebut. Salah satu pendekatannya adalah Screen-Smart Device Interaction (SSI). Pada penelitian ini, dikembangkan sebuah interaksi untuk menampilkan sebuah file dari smart device ke sebuah display menggunakan antar muka berbasis Chat. Pengujian dilakukan dengan alat ukur SUS dan UEQ-S. Dari pengujian diperoleh kesimpulan bahwa hasil yang dikembangkan termasuk kategori acceptable dengan skor SUS 72.8. Akan tetapi dari UEQ-S diperoleh skor hedonic yang lebih rendah dari pragmatic, yang artinya perlu pengembangan lebih lanjut terkait tampilan dari prototype yang diujikan.

Keywords-public display, tampilan publik, media informasi, desain interaksi, chatbot, usability, kesadaran bencana

\section{PENDAHULUAN}

Indonesia merupakan negara yang memiliki resiko bencana alam yang tinggi. Risiko ini juga meningkat mengingat kerentanan sosial dan ekonomi penduduk. Sejak tahun 1900, telah terjadi 429 bencana alam dengan bentuk yang paling sering terjadi adalah banjir dan gempa bumi. Ada kematian lebih dari 238.000 dan korban yang terkena melebihi 29 juta [1].
Untuk mengatasi hal tersebut, ada konsep pengurangan risiko bencana [2]. Yang terdiri dari dua tahap besar yaitu mitigasi dan kesiapsiagaan. Salah satu tahapan kesiapsiagaan diimplementasikan dalam bentuk sistem peringatan dini. Untuk bencana tsunami, Indonesia sudah memiliki sistem end-to-end yang disebut InaTEWS [3].

InaTEWS terdiri dari beberapa bagian utama, salah satunya adalah penyebaran informasi dan peringatan. Saat ini, InaTEWS telah mendukung beberapa mode penyebaran termasuk Sirene, Web, Fax, Email, SMS, dan Warning Receiver System (WRS). Moda-moda tersebut memiliki kesamaan fungsi sebagai media informasi publik. Terutama mode WRS yang didesain untuk disalurkan melalui instansi terkait dan melalui DVB milik stasiun TV.

Di sisi lain, banyak TV publik yang dipasang tidak hanya di pusat perbelanjaan tetapi juga di perkantoran dan di layanan publik. Fenomena ini memunculkan peluang pemanfaatan baru yaitu pervasive display [4]. Pervasive display secara sederhana dapat diartikan sebagai tampilan yang terhubung ke Internet. Ada banyak perspektif terkait hal ini, salah satunya adalah pervasive display sebagai platform sekaligus WRS [5].

Untuk membuat pervasive display sebagai platform, banyak hal yang perlu diselesaikan. Salah satunya adalah mengubah penggunaan public display saat ini. Public display kini banyak digunakan untuk menampilkan informasi di ruang publik seperti pusat perbelanjaan. Umumnya digunakan untuk menampilkan iklan. Beberapa penelitian menunjukkan bahwa public display seringkali tidak relevan dengan lokasi dan sering diabaikan oleh orang yang lewat. Tetapi pada saat yang sama, mereka menunjukkan bahwa ada peluang untuk meningkatkan penggunaan tampilan publik dengan mengintegrasikannya dengan perangkat pribadi seperti smartphone dan jam tangan pintar [6].

Peluang integrasi ini memunculkan permasalahan baru, yaitu bentuk interaksi antara smart device dan public display. Bentuk interaksi ini adalah salah satu sub-domain penelitian pervasive display, juga disebut Screen-Smart Device Interaction (SSI). Ada beberapa bentuk interaksi yang telah dipelajari sebelumnya seperti smartphone sebagai remote [7], dan smartphone sebagai alat untuk mengambil konten dari tampilan publik [8].

Studi ini bertujuan untuk mengeksplorasi lebih jauh tentang penggunaan ponsel pintar untuk mengelola konten 
pada tampilan publik. Pekerjaan sebelumnya telah dilakukan dengan menggunakan QR-Code sebagai modal untuk berinteraksi dengan tampilan publik [9]. Dari hasil pengukuran yang telah dilakukan disimpulkan bahwa perlu dikembangkan lebih lanjut. Dengan demikian, penelitian ini melanjutkan pekerjaan pada fase pemasangan perangkat dan modalitas interaksi seperti yang didefinisikan dalam [10].

\section{PENELITIAN TERKAIT}

Ada beberapa karya yang berhubungan dengan public display dan SSI. Karya-karya ini dapat dikelompokkan ke dalam perspektif yang berbeda. Mulai dari public display untuk bencana, kemudian penggunaan perangkat pintar untuk mengontrol tampilan publik. Juga definisi SSI itu sendiri. SSI adalah topik yang luas, salah satu kategorinya adalah penggunaan interaksi berbasis percakapan. Dan salah satu bentuk interaksi percakapan yang umum adalah chat. Dalam perspektif terakhir, ada beberapa karya berbasis chat yang akan dibahas.

\section{A. Public display untuk kebencanaan}

Ada beberapa kegunaan public display untuk tujuan bencana. Salah satunya adalah papan informasi yang memungkinkan pengguna untuk mengambil konten yang mereka butuhkan menggunakan perangkat seluler yang mereka miliki [11]. Studi ini menggunakan studi kasus gempa bumi di bagian timur Jepang tahun 2011. Salah satu peristiwa yang diamati adalah berkumpulnya banyak orang di depan papan informasi yang menyebabkan terjadinya kepadatan yang tidak terduga. Diharapkan dengan sistem yang diusulkan, warga dapat memperoleh informasi yang diperlukan melalui koneksi Wi-Fi. Setelah setiap warga mendapatkan informasi yang diinginkan, diharapkan tidak ada lagi penumpukan massa di depan papan informasi.

Serupa dengan penelitian tersebut, penelitian lain dilakukan dengan studi kasus serupa yaitu pada situasi bencana [8]. Perbedaannya terletak pada bentuk interaksi yang diberikan. Interaksi yang disediakan memungkinkan masyarakat umum untuk menambahkan konten ke tampilan publik yang ada. Sistem ini diharapkan dapat digunakan sebagai media untuk berbagi informasi saat terjadi bencana. Studi ini menawarkan beberapa konsep manajemen tugas dan kegiatan sukarela spontan.

Peneliti lain mengidentifikasi satu set pertimbangan desain [12]. Setelah mereka mengevaluasi dua desain yang berbeda untuk sistem pesan darurat di masa depan dalam jaringan tampilan publik, mereka menemukan serangkaian pertimbangan desain termasuk penggunaan kembali konten yang terbatas, penjadwalan konten langsung, penargetan wilayah geografis secara bersamaan, dan pertimbangan pemadaman listrik atau saluran komunikasi alternatif. Singkatnya, tampilan publik hanyalah bagian dari sistem penyebaran yang digunakan jika diperlukan.

\section{B. Perangkat Cerdas untuk Remote Control Public Display [7]}

Riset ini mengkombinasikan perangkat pintar dengan public display. Di mana perangkat pintar diposisikan sebagai remote control untuk public display. Sebagai remote control, artinya sistem ini ditujukan untuk pemilik public display. Sistem ini dapat digunakan untuk mengelola tampilan publik. Namun belum ditelaah lebih jauh mengenai posisi sistem ini terhadap relawan atau orang yang lalu-lalang di public display. Penelitian ini juga belum menggali manfaat yang mendukung penggunaan public display sebagai papan informasi publik.

\section{Screen-Smart Device Interaction (SSI) [10]}

Screen-Smart Device Interaction (SSI) adalah domain interaksi dengan tampilan publik yang memiliki karakteristik interaksi tidak langsung. Ciri ini berbeda dengan interaksi pada tampilan publik pada umumnya yang menambahkan fitur interaksi langsung pada tampilan publik berupa layar sentuh atau kamera untuk menangkap gestur. Dimana interaksi ini juga bisa disebut sebagai Human-Screen Interaction.

SSI terdiri dari tiga komponen utama, yaitu Layar, Perangkat Cerdas, dan Modalitas Interaksi (suatu bentuk interaksi). Layar, dalam hal ini, mengacu pada tampilan publik itu sendiri. Perangkat Cerdas mengacu pada peralatan yang digunakan oleh pengguna. Peralatan ini tidak terbatas pada smartphone tetapi juga dapat dipakai seperti jam tangan pintar. Spesifikasi utama yang dibutuhkan dari peralatan ini adalah koneksi nirkabel. Komponen terakhir adalah Modalitas Interaksi, mengacu pada penggunaan fitur-fitur di perangkat pintar untuk berinteraksi dengan tampilan publik. Salah satu aspek dari interaksi yang terlihat adalah bagaimana interaksi real-time dapat dilakukan antara perangkat pintar dan tampilan publik.

Berikut adalah beberapa perbedaan antara SSI dan Interaksi Layar Manusia seperti yang ditunjukkan pada Tabel I. Perbedaan ini termasuk jenis layar yang dibutuhkan, perangkat yang digunakan pengguna, dan jarak yang dibutuhkan untuk berinteraksi.

TABEL I. PERBEDAAN ANTARA SSI DAN HUMAN-SCREEN INTERACTION

\begin{tabular}{|l|l|}
\hline $\begin{array}{l}\text { Screen-Smart Device } \\
\text { Interaction (SSI) }\end{array}$ & Human-Screen Interaction \\
\hline Layar TV biasa & $\begin{array}{l}\text { Layar TV dengan touch screen } \\
\text { atau kamera }\end{array}$ \\
\hline $\begin{array}{l}\text { Pengguna berinteraksi melalui } \\
\text { smart devices }\end{array}$ & $\begin{array}{l}\text { Pengguna berinteraksi langsung } \\
\text { de }\end{array}$ \\
\hline $\begin{array}{l}\text { Pengguna harus membawa sebuah } \\
\text { smart device }\end{array}$ & $\begin{array}{l}\text { Pengguna tidak perlu membawa } \\
\text { apapun }\end{array}$ \\
\hline $\begin{array}{l}\text { Pengguna tidak dibatasi oleh jarak } \\
\text { dengan layar }\end{array}$ & $\begin{array}{l}\text { Pengguna harus dalam jarak yang } \\
\text { dekat dengan layar, terutama } \\
\text { untuk layar touch screen }\end{array}$ \\
\hline
\end{tabular}

Pada umumnya, interaksi pengguna dengan sebuah display dilakukan secara langsung menggunakan sensor yang ditanam di layer baik berupa sensor sentuh maupun sensor kamera. SSI merupakan metode yang berusaha melakukan sebaliknya, dimana display yang digunakan minim sensor dan memanfaatkan display sekunder berupa smartphone. Pendekatan ini dilakukan mengingat keberadaan smartphone 


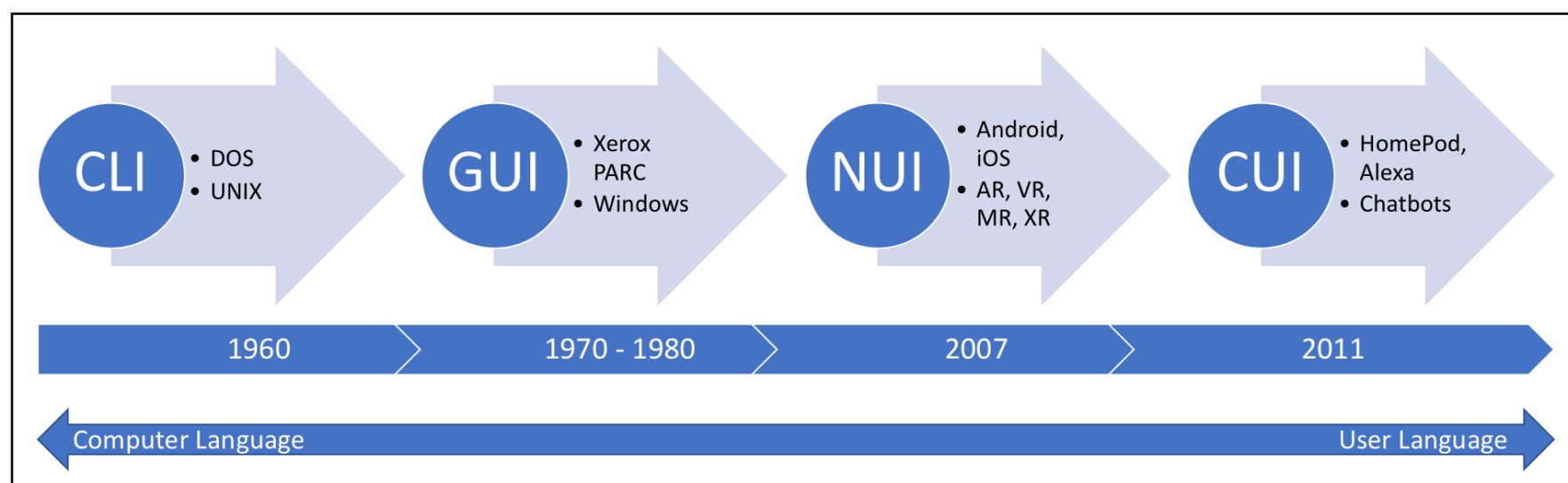

Gambar. 1. History of Computer Interfaces

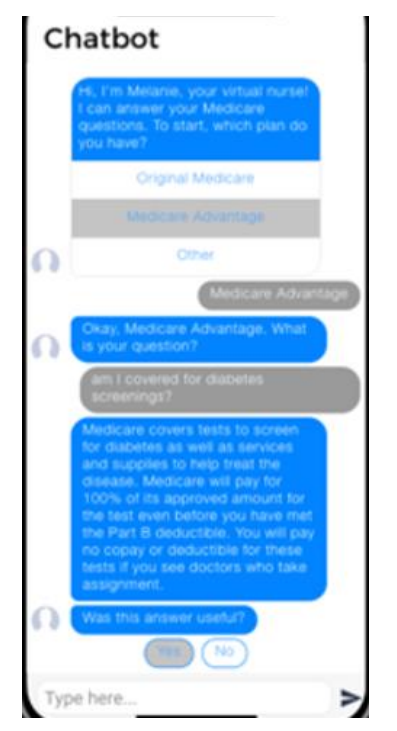

Gambar. 2. Contoh Visual-Centric Style

yang hampir dimiliki oleh semua orang. Harapannya, melalui SSI, pengguna bisa tertarik menggunakan public display.

Modalitas Interaksi dapat direalisasikan melalui dua teknologi utama, yaitu koneksi perangkat dan saluran komunikasi data. Ide utama SSI adalah penggunaan teknologi yang sudah ada yaitu Smart TV dan Smart Device. Kemudian mendesain bentuk interaksi di atasnya.

\section{Conversational Interaction [13]}

Cara pengguna berinteraksi dengan komputer bervariasi dari waktu ke waktu seperti yang ditunjukkan pada Gambar. 1. Interaksi berkembang dari Command-Line Interfaces (CLI) menjadi Graphical User Interfaces (GUI). Kemudian disusul dengan hadirnya smartphone yang menghadirkan Natural User Interfaces (NUI). Tren ini sebenarnya adalah pergeseran interaksi dimana awalnya pengguna harus belajar bahasa komputer. Tetapi komputer hari ini dilatih untuk berbicara bahasa pengguna. Tren ini mengarah pada munculnya antarmuka pengguna percakapan (CUI).

Evolusi ini juga mengarah pada munculnya disiplin desain pengalaman pengguna (UX). Desainer mengalihkan fokus mereka dari desain berbasis teknologi ke pengalaman penuh yang diperoleh orang saat berinteraksi dengan teknologi. Pergeseran desain ini disebut juga desain yang berpusat pada manusia.

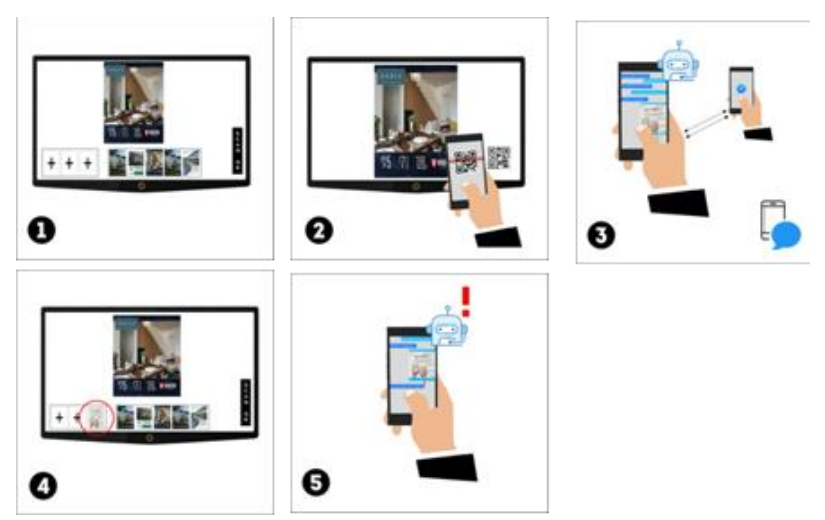

Gambar. 3. Desain interaksi berbasis SSI. (1) Sebuah public display (2) Pengguna memindai QR Code (3) QR Code mengarahkan ke Messenger dimana interaksi terjadi (4) Gambar ditampilkan pada display (5) Pengguna mendapat notifikasi melalui Messenger.

Platform chatbot saat ini memungkinkan seorang desainer untuk membuat berbagai gaya interaksi yang berbeda. Ada empat gaya interaksi yang berbeda: berpusat pada sistem, berpusat pada konten, berpusat pada visual, dan berpusat pada percakapan. Setiap gaya menekankan aspek antarmuka yang berbeda. Khususnya gaya visual-sentris, ini menggabungkan elemen grafis seperti tombol bersama dengan dialog yang biasa digunakan di antarmuka web dan seluler. Gaya percakapan ini memberikan jawaban yang telah ditentukan sebelumnya untuk pengguna. Contoh gaya ini ditunjukkan pada Gambar 2.

\section{E. Interaksi Berbasis Obrolan}

Pekerjaan di [14] mempelajari penggunaan aplikasi obrolan dalam konteks pengembangan bahasa. Mereka menggunakan aplikasi yang umumnya tersedia seperti WhatsApp dan Facebook. Mereka menggunakan WhatsApp untuk mewakili komunikasi berbasis obrolan seluler dan Facebook untuk mewakili percakapan berbasis obrolan komputer. Mereka mempelajari perbedaan antara keterlibatan kognitif dan keterlibatan emosional di komputer dan lingkungan seluler. Perbedaan pertama adalah jumlah pesan di antara kedua lingkungan tersebut. Perbedaan tersebut menegaskan bahwa aplikasi berbasis mobile chat lebih sering digunakan daripada berbasis komputer. Perbedaan berikutnya adalah waktu balasan antar percakapan menunjukkan bahwa 


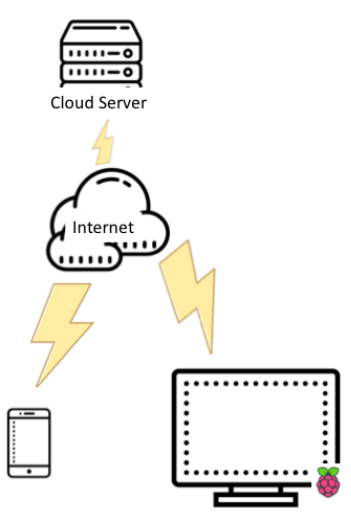

Gambar. 4. Konfigurasi perangkat keras untuk implementasi

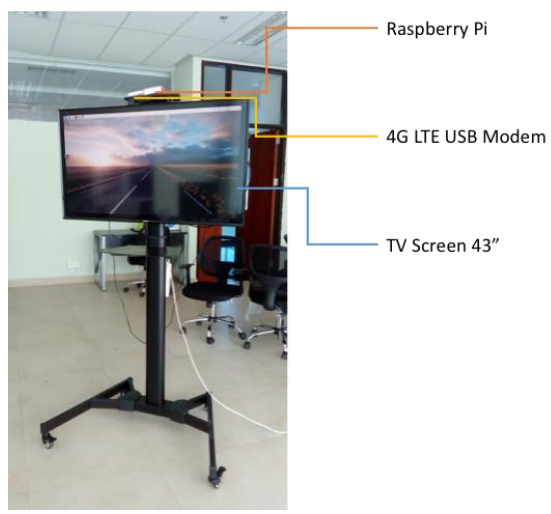

Gambar. 5. Contoh implementasi Smart TV

percakapan terjadi lebih sinkron di ponsel daripada di komputer.

Di [15], chatbot dibuat untuk membantu pengguna membuat log aktivitas harian mereka. Ini juga menggabungkan obrolan berbasis teks dengan obrolan berbasis suara. Sebagian besar data yang diolah berbentuk teks. Chatbot dirancang untuk mengajukan beberapa pertanyaan setiap hari.

Dalam [16], chatbot dirancang untuk membangun dialog interaktif untuk melibatkan pengunjung. Ini juga dirancang untuk menjadi panduan virtual. Ia mencoba untuk melengkapi aplikasi museum berbasis browser atau asli dengan mengadopsi antarmuka obrolan Messenger. Ia mencoba memberikan deskripsi artefak museum dalam pengalaman mengobrol.

\section{F. Teknik Interaksi untuk Mentransfer File}

Karya di [17] memiliki beberapa persamaan dan perbedaan dengan karya kami sebelumnya [9]. Keduanya memiliki kesamaan dalam memungkinkan pengguna mengunggah konten ke tampilan publik. Tetapi pekerjaan di [17] lebih lengkap daripada [9] dengan menambahkan mekanisme logging dan enkripsi. Ini menggunakan antarmuka berbasis web untuk memungkinkan pengguna mengunggah konten ke tampilan.

\section{DESAIN DAN IMPLEMENTASI}

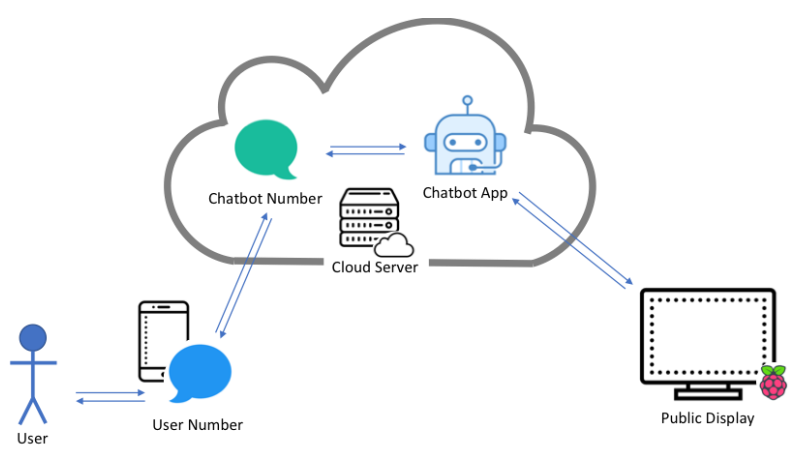

Gambar. 6. Arsitektur perangkat lunak untuk implementasi

Rancangan alur interaksi ditunjukkan pada Gambar 3. Perancangan mengimplementasikan pemasangan perangkat dan saluran komunikasi data dalam satu langkah, dengan menggunakan QR Code yang mengarahkan pengguna ke Facebook Messenger. Pemasangan perangkat diimplementasikan sebagai memasangkan Facebook Messenger dengan tampilan publik. Sedangkan jalur komunikasi data diimplementasikan melalui aplikasi chatting Facebook Messenger. Di Facebook Messenger, pertukaran data terjadi dalam bentuk obrolan biasa. Ini tidak memerlukan formulir masukan khusus untuk mengirim file.

TABEL II. PLATFORM-PLATFORM YANG DIGUNAKAN PADA MASINGMASING BAGIAN SISTEM

\begin{tabular}{|l|l|}
\hline Platform & Vendor \\
\hline Messaging & Facebook Messenger $^{1}$ \\
\hline Bot Chat & Chatfuel $^{2}$ \\
\hline Cloud Function & Pipedream $^{3}$ \\
\hline Tunneling & Ngrok $^{4}$ \\
\hline
\end{tabular}

Untuk mengimplementasikan desain tersebut, dibuat konfigurasi perangkat keras seperti pada Gambar 4. Sistem perangkat keras terdiri dari tiga bagian utama yaitu perangkat pintar, server cloud, dan smart TV. Semua bagian terhubung ke internet. Perangkat pintar disediakan oleh pengguna. Dan server cloud dapat disediakan oleh vendor. Sedangkan bagian smart TV merupakan bagian yang perlu dikembangkan karena saat ini kami belum menemukan smart TV yang didesain untuk public display.

Ada banyak variasi Smart TV. Setiap vendor memiliki spesialisasinya sendiri. Tetapi mereka semua memiliki kesamaan yang terdiri dari sistem operasi dan koneksi internet. Versi Smart TV yang disederhanakan dapat dibuat menggunakan TV biasa yang dilengkapi dengan raspberry dan modem USB seperti yang ditunjukkan pada Gambar 5.

Kemudian di atas konfigurasi perangkat keras, disusun beberapa bagian perangkat lunak dengan masing-masing kegunaan dan fungsinya. Penggunaan masing-masing bagian perangkat lunak ditunjukkan pada Gambar 6. Untuk membangun interaksi percakapan, perangkat pintar digunakan sebagai chat client. Kemudian di cloud, ada server chat dan

\footnotetext{
${ }^{1}$ https://developers.facebook.com/docs/messenger-platform

${ }^{2}$ https://chatfuel.com
}

\footnotetext{
${ }^{3}$ https://pipedream.com

${ }^{4}$ https://ngrok.com
} 


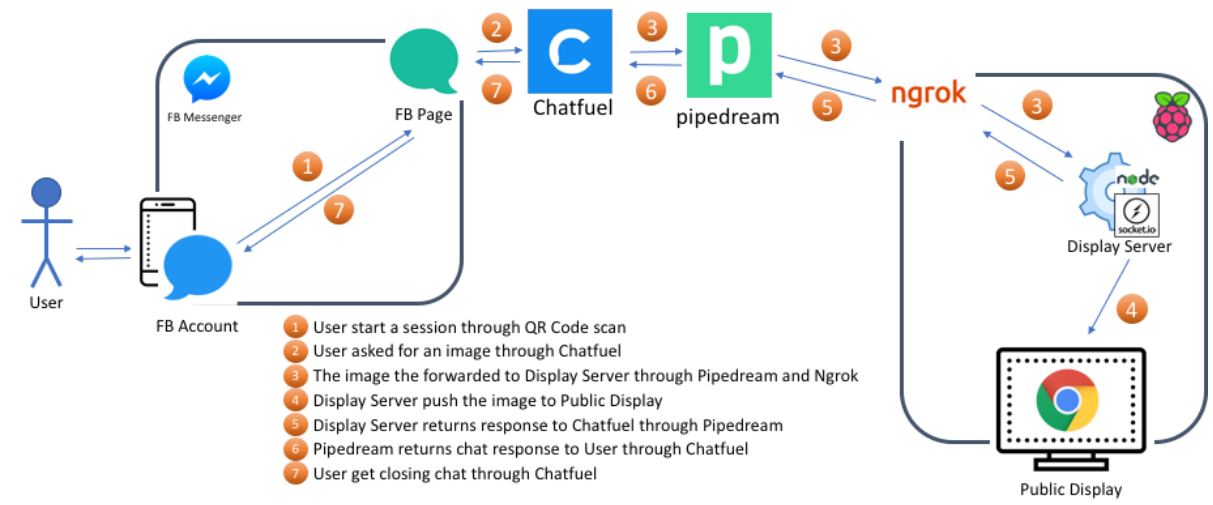

Gambar. 7. Keseluruhan implementasi dari arsitektur software, (1) Pengguna memindai QR Code kemudian memulai sesi chat di FB Messenger (2) Pengguna diminta sebuah gambar melalui Chatfuel (3) Gambar tersebut kemudian diteruskan ke display melalui Pipedream dan Ngrok (4) Display Server mengirim gambar tersebut ke public display (5) Display Server memberikan respon balik ke Chatfuel melalui Pipedream (6) Pipedream mengembalikan respon chat kepada pengguna melalui Chatfuel (7) Pengguna memperoleh chat penutup melalui Chatfuel

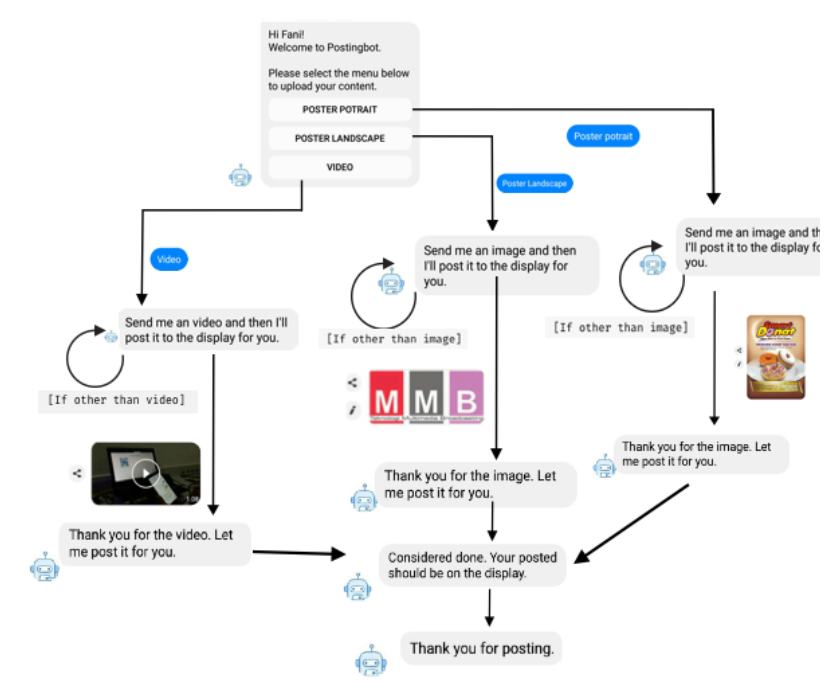

Gambar. 8. Implementasi Aliran Chat pada Chatfuel

chatbot. Chat server ini berkomunikasi dengan aplikasi chatbot. Selanjutnya, aplikasi chatbot mengirimkan instruksi ke tampilan publik atas nama pengguna.

Untuk mengimplementasikan arsitektur perangkat lunak seperti yang ditunjukkan pada Gambar 6, terdapat banyak platform yang digunakan untuk setiap bagian sistem seperti yang ditunjukkan pada Tabel II. Setiap bagian dari sistem memiliki fungsi dan tanggung jawabnya. Platform messaging mewakili sistem yang memungkinkan pengguna untuk mengobrol. Platform chatbot mewakili bot yang akan merespons obrolan. Public display adalah bagian yang memungkinkan modifikasi jarak jauh seperti memposting konten baru. Bagian public display dikembangkan secara khusus dalam pekerjaan ini, sedangkan bagian lainnya dikembangkan di atas platform yang ada yang disediakan oleh beberapa vendor seperti yang ditunjukkan pada Tabel II. Data dan aliran eksekusi antara semua bagian ditunjukkan pada Gambar. 7. Tunnel service yang disediakan oleh Ngrok digunakan untuk mengaktifkan domain langsung secara instan untuk aplikasi public display yang dikembangkan secara lokal.

Alur percakapan diimplementasikan di Chatfuel. Alur percakapan yang lengkap ditunjukkan pada Gambar 8. Titik awal percakapan adalah menanyakan kepada pengguna jenis konten yang ingin mereka posting untuk ditampilkan.
Kemudian digunakan pengulangan dasar berupa pesan "send me an ..." hingga pengguna memberikan jenis input yang tepat. Setelah pengguna memberikan input yang benar, kemudian memanggil API untuk memposting input ke tampilan publik. Titik akhir API akan merespons dengan pesan obrolan jika gambar berhasil dikirim. Kemudian bot memberikan penutup obrolan dengan pesan "terima kasih telah memposting".

\section{HASIL DAN DISKUSI}

Pengujian pengukuran pengguna dilakukan di tengahtengah pandemi, sehingga ada beberapa penyesuaian yang dilakukan dalam melakukan pengujian. Tes dilakukan secara virtual menggunakan platform pertemuan online. Tampilan layar publik dibagi dengan pengguna melalui platform seperti yang ditunjukkan pada Gambar 10. Interaksi antara pengguna dan bot ditunjukkan pada Gambar 9.

Metrik yang digunakan untuk pengukuran adalah SUS [18] dan UEQ-S [19]. Salah satu kegunaan utama SUS adalah untuk memutuskan apakah suatu produk dapat diterima atau

TABEL III. HASIL PENGUKURAN

\begin{tabular}{|c|c|c|c|}
\hline \multicolumn{3}{|c|}{ Jumlah Responden } & 38 \\
\hline \multirow{4}{*}{ SUS } & \multicolumn{2}{|l|}{ Skor } & 72.8 \\
\hline & \multicolumn{2}{|l|}{ Kategori } & Bagus \\
\hline & \multicolumn{2}{|l|}{ Nilai } & $\mathrm{C}$ \\
\hline & \multicolumn{2}{|l|}{ Penerimaan } & $\begin{array}{l}\text { Dapat } \\
\text { Diterima }\end{array}$ \\
\hline \multirow{8}{*}{$\begin{array}{l}\text { UEQ- } \\
\text { S }\end{array}$} & \multirow{3}{*}{$\begin{array}{l}\text { Kualitas } \\
\text { Pragmatis }\end{array}$} & Skala & 1.850 \\
\hline & & Terhadap Acuan & Excellent \\
\hline & & Cronbach's Alpha Coefficient & 0.74 \\
\hline & \multirow{3}{*}{$\begin{array}{l}\text { Kualitas } \\
\text { Hedonis }\end{array}$} & Skala & 1.388 \\
\hline & & Terhadap Acuan & $\begin{array}{l}\text { Above } \\
\text { Average }\end{array}$ \\
\hline & & Cronbach's Alpha Coefficient & 0.88 \\
\hline & \multirow{2}{*}{ Keseluruhan } & Skala & 1.619 \\
\hline & & Terhadap Acuan & Good \\
\hline
\end{tabular}



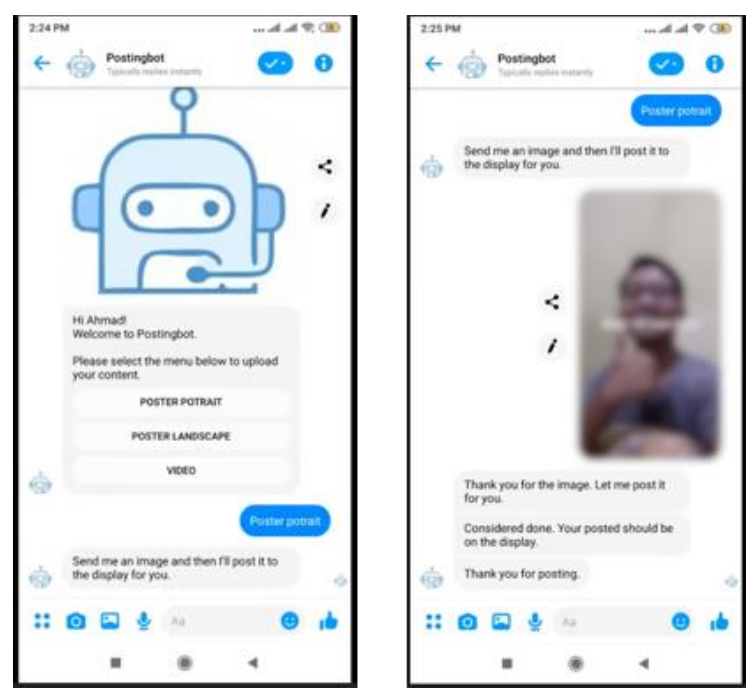

Gambar. 9. Contoh percakapan chat

tidak. Sejarah SUS dimulai pada 1980-an, awalnya digambarkan oleh pencetusnya sebagai "quick and dirty usability scale". Seiring waktu terbukti cepat tapi tidak "kotor". Ini diprediksi akan menjadi ukuran kegunaan populer di masa mendatang [20]. Meskipun SUS memiliki skor dalam rentang 0 hingga 100, bukan berarti skor tinggi mewakili produk teratas. Sebagaimana dinyatakan dalam [21], aplikasi teratas memiliki skor rata-rata 80 .

UEQ-S digunakan untuk mengukur dua karakteristik utama suatu aplikasi, yaitu hedonis dan pragmatis. Kualitas hedonis merepresentasikan kualitas penampilan. Dan kualitas pragmatis mewakili fungsionalitas aplikasi dari perspektif pengguna. Mirip dengan SUS, UEQ-S menggunakan daftar pertanyaan yang secara statistik mewakili kualitas tersebut.

Sebagaimana dibahas dalam [22], skor SUS dapat diinterpretasikan dalam beberapa cara. Beberapa interpretasi ditunjukkan pada Tabel III. Perhatian utama kami adalah interpretasi penerimaan. di SUS, dapat diterima sesuai dengan skor di atas rata-rata 68 yang berarti pekerjaan ini dianggap dapat diterima. Penafsiran ini penting karena dapat digunakan untuk memutuskan apakah akan melanjutkan pekerjaan ini atau tidak.

Hasil UEQ-S menunjukkan bahwa prototipe secara keseluruhan memiliki skor "Baik". Jika kita membandingkan skor hedonis dan pragmatis, dapat disimpulkan bahwa aspek pragmatis lebih tinggi daripada hedonis. Artinya, pengguna memahami fungsionalitas yang ditawarkan tetapi masih mengharapkan beberapa peningkatan pada tampilan. Dalam hal koefisien alpha Cronbach, kita dapat menyimpulkan bahwa persepsi tentang kualitas hedonis lebih cenderung benar daripada kualitas pragmatis.

\section{KESIMPULAN}

Pekerjaan ini mengusulkan model interaksi untuk tampilan publik menggunakan pendekatan Screen-Smart Device Interaction (SSI). Pendekatan tersebut digunakan untuk aktivitas posting konten pada tampilan publik. Pendekatan tersebut diimplementasikan dalam bentuk chat untuk mentransfer file antara smartphone dan tampilan publik.

Berdasarkan pengukuran SUS terhadap 38 responden dianggap dapat diterima. Dan itu juga dianggap sebagai

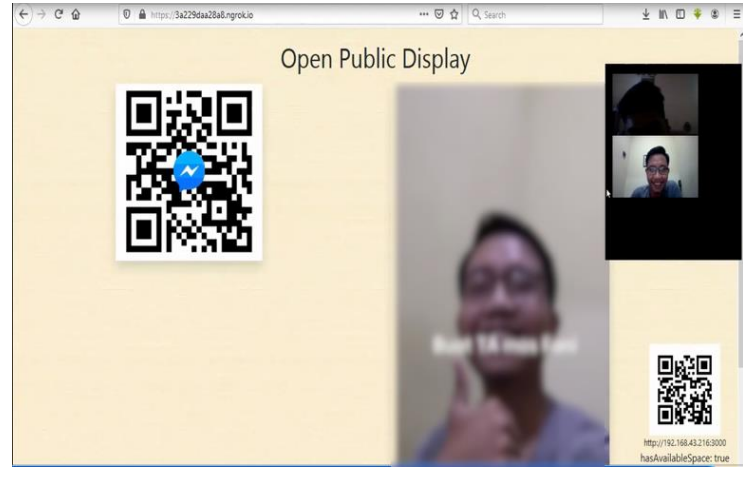

Gambar. 10. Contoh hasil percakapan pada public display

prototipe yang baik berdasarkan pengukuran UEQ-S. Dapat disimpulkan bahwa pekerjaan ini memiliki kemungkinan untuk dieksplorasi lebih lanjut.

Tetapi hasil ini masih jauh dari selesai. Karena prototipe itu sendiri bukanlah aplikasi yang lengkap, jadi ada kemungkinan bahwa versi lengkap mungkin memiliki kerumitan yang dapat mengurangi kegunaan. Ruang lain untuk diperbaiki adalah jumlah responden. Dibandingkan dengan karya lain seperti yang dijelaskan dalam [20], karya ini perlu menambah jumlah responden.

\section{PENGHARGAAN}

Pekerjaan ini didukung oleh Politeknik Elektronika Negeri Surabaya dalam skema "Penelitian Lokal Tingkat 2", Surat Keputusan Nomor 2944/PL14/PG/2019 dalam Kontrak Nomor 068/PL14/PG.1/2019 dan Surat Keputusan Nomor 1778/PL14/PG/2020.

\section{REFERENSI}

[1] G. Surtiari, "PENTINGNYA PENANGANAN PASCABENCANA YANG BERFOKUS PADA PENDUDUK UNTUK MEWUJUDKAN BUILD BACK BETTER: PEMBELAJARAN DARI BENCANA PALU, SIGI, DAN DONGGALA", Jurnal Kependudukan Indonesia, vol. 14 , no. 2, p. 165 , 2020. Available: 10.14203/jki.v14i2.443 [Accessed 19 May 2021].

[2] Syamsidik et al., "Challenges in increasing community preparedness against tsunami hazards in tsunami-prone small islands around Sumatra, Indonesia", International Journal of Disaster Risk Reduction, vol. 47, p. 101572, 2020. Available: 10.1016/j.ijdrr.2020.101572 [Accessed 19 May 2021].

[3] S. Harig et al., "The Tsunami Scenario Database of the Indonesia Tsunami Early Warning System (InaTEWS): Evolution of the Coverage and the Involved Modeling Approaches", Pure and Applied Geophysics, vol. 177, no. 3, pp. 1379-1401, 2019. Available: 10.1007/s00024-019-02305-1 [Accessed 19 May 2021].

[4] F. Alt and J. Vehns, "Opportunistic deployments", Proceedings of the 5th ACM International Symposium on Pervasive Displays, 2016. Available: 10.1145/2914920.2915020 [Accessed 20 May 2021].

[5] J. Mambu and J. Gutierrez, "Emergency broadcast system: A reverse 911 tsunami information dissemination system prototype", 2016 26th International Telecommunication Networks and Applications Conference (ITNAC), 2016. Available: 10.1109/atnac.2016.7878783 [Accessed 20 May 2021].

[6] C. Parker, M. Hoggenmueller and M. Tomitsch, "Design Strategies for Overcoming Failures on Public Interactive Displays", Proceedings of the 7th ACM International Symposium on Pervasive Displays, 2018. Available: 10.1145/3205873.3205889 [Accessed 20 May 2021].

[7] M. Barsotti, F. Paternò and F. Pulina, "A web framework for crossdevice gestures between personal devices and public displays", Proceedings of the 16th International Conference on Mobile and Ubiquitous Multimedia, 2017. Available: 10.1145/3152832.3152858 [Accessed 20 May 2021].

[8] B. Guo, Y. Liu, L. Wang, V. Li, J. Lam and Z. Yu, "Task Allocation in Spatial Crowdsourcing: Current State and Future Directions", IEEE Internet of Things Journal, vol. 5, no. 3, pp. 1749-1764, 2018. Available: 10.1109/jiot.2018.2815982 [Accessed 20 May 2021]. 
[9] R. Aoki et al., "An Information Display System with Information Scrapping User Interface Based on Digital Signage Terminals and Mobile Devices for Disaster Situations", Lecture Notes in Computer Science, pp. 353-363, 2016. Available: 10.1007/978-3-319-395166_34 [Accessed 20 May 2021].

[10] P. C. Ng, J. She, K. E. Jeon, and M. Baldauf, "When Smart Devices Interact With Pervasive Screens: A Survey," ACM Transactions on Multimedia Computing, Communications and Applications, vol. 13, pp. 1-23, aug 2017.

[11] R. Aoki et al., "An Information Display System with Information Scrapping User Interface Based on Digital Signage Terminals and Mobile Devices for Disaster Situations", Lecture Notes in Computer Science, pp. 353-363, 2016. Available: 10.1007/978-3-319-395166_34 [Accessed 20 May 2021].

[12] A. Almutairi, M. Mikusz, H. Niaz, L. Trotter, and N. Davies, "Why simple is best: Lessons from designing an emergency system for public displays," in Proceedings - Pervasive Displays 2019 - 8th ACM International Symposium on Pervasive Displays, PerDis 2019, (New York, New York, USA), pp. 1-7, ACM Press, 2019.

[13] R. J. Moore, "Studies in Conversational UX Design," no. November, pp. 181-204, 2018.

[14] E. Tragant, À. Pinyana, J. Mackay and M. Andria, "Extending language learning beyond the EFL classroom through WhatsApp", Computer Assisted Language Learning, pp. 1-30, 2021. Available: 10.1080/09588221.2020.1854310 [Accessed 20 May 2021].

[15] R. Kocielnik, L. Xiao, D. Avrahami and G. Hsieh, "Reflection Companion", Proceedings of the ACM on Interactive, Mobile, Wearable and Ubiquitous Technologies, vol. 2, no. 2, pp. 1-26, 2018. Available: 10.1145/3214273 [Accessed 20 May 2021]
[16] G. Gaia, S. Boiano and A. Borda, "Engaging Museum Visitors with AI: The Case of Chatbots", Museums and Digital Culture, pp. 309-329, 2019. Available: 10.1007/978-3-319-97457-6_15 [Accessed 20 May 2021].

[17] R. Nakai and T. Ishida, "Implementation of an Interactive Information Sharing System for Disaster Measure Operation", International Journal of Mobile Computing and Multimedia Communications, vol. 11, no. 1, pp. 1-22, 2020. Available: 10.4018/ijmcmc.2020010101 [Accessed 20 May 2021].

[18] Z. Sharfina and H.B. Santoso, "An Indonesian adaptation of the System Usability Scale (SUS)," in 2016 International Conference on Advanced Computer Science and Information Systems, ICACSIS 2016, pp. 145148, IEEE, oct 2017.

[19] M. Schrepp, A. Hinderks, and J. Thomaschewski, "Design and Evaluation of a Short Version of the User Experience Questionnaire (UEQ-S)," International Journal of Interactive Multimedia and Artificial Intelligence, vol. 4, no. 6, p. 103, 2017.

[20] J. Lewis, "Measuring Perceived Usability: SUS, UMUX, and CSUQ Ratings for Four Everyday Products", International Journal of HumanComputer Interaction, vol. 35, no. 15, pp. 1404-1419, 2018. Available: 10.1080/10447318.2018.1533152 [Accessed 20 May 2021].

[21] A.Kaya, R.Ozturk, and C. Altin Gumussoy, "Usability Measurement of Mobile Applications with System Usability Scale (SUS)," pp. 389400, Springer, Cham, 2019.

[22] A. Bangor, P. Kortum and J. Miller, "An Empirical Evaluation of the System Usability Scale", International Journal of Human-Computer Interaction, vol. 24, no. 6, pp. 574-594, 2008. Available: 10.1080/10447310802205776 [Accessed 20 May 2021]. 